\title{
SERUM KINETICS OF Calloselasma rhodostoma (MALAYAN PIT VIPER) VENOM COMPONENTS IN A RABBIT
}

\author{
Tan NH (1), Ponnudurai G (2), Fung SY (1)
}

(1) Department of Molecular Medicine, Faculty of Medicine, University of Malaya, Kuala Lumpur, Malaysia; (2) International Medical University, Kuala Lumpur, Malaysia.

ABSTRACT: The serum kinetics of Calloselasma rhodostoma (Malayan pit viper) venom - specifically two of its components, the major hemorrhagin (rhodostoxin) and a thrombin-like enzyme - was examined in a rabbit by double-sandwich enzymelinked immunosorbent assay (ELISA). The animal received intramuscularly a 1.0$\mathrm{mg} / \mathrm{kg}$ dose of $C$. rhodostoma venom. The venom level in serum peaked 12 hours after the injection, followed by a gradual decline and finally reached low rates 72 hours after administration. The serum kinetic profile of venom components, however, did not correspond to the profile of the whole $C$. rhodostoma venom. The serum levels of the $C$. rhodostoma thrombin-like enzyme increased slowly and peaked only 48 hours post-injection. Then both thrombin-like enzyme and rhodostoxin remained at relatively high levels 72 hours after administration. Data suggest that various venom components bind to tissue at the injection site with different affinities and that conjugated venom components were continuously released into circulation at different rates. The prolonged high serum levels of both thrombin-like enzyme and hemorrhagin are consistent with the clinical picture of prolonged clotting deficiency in severe cases of $C$. rhodostoma envenomation. Our results also suggest that since venom components are being released into and eliminated from the circulation at different rates, the "average composition" of the venom antigen in the circulation changes over time. This implies that data from ELISA quantification of antigen levels from serum venom employing "whole venom" as reagent must be interpreted with care.

KEY WORDS: Calloselasma rhodostoma venom, thrombin-like enzyme, hemorrhagin, serum kinetics, rabbit, ELISA.

CONFLICTS OF INTEREST: There is no conflict.

FINANCIAL SOURCE: Government of Malaysia.

\section{CORRESPONDENCE TO:}

NGET HONG TAN, Department of Molecular Medicine, Faculty of Medicine, University of Malaya, Kuala Lumpur, Malaysia. Phone: +60 37967 4912. Fax: +60 3 7967 4957. Email: tanngethong@yahoo.com.sg. 


\section{INTRODUCTION}

Recently, ELISA has been employed in studies on serum kinetics of snake venom or venom components in mice, rabbits, dogs as well as in humans (1-7). The information on serum kinetics of envenomated victims is important to the development of a personalized modality of treatment, in which the dose and frequency of antivenom administration are based on the amount of venom injected and on the kinetics of venom distribution in the body $(1,4,6)$. We report herein our investigation of the serum kinetics of Calloselasma rhodostoma (Malayan pit viper) venom and its two main toxins (the hemorrhagic rhodostoxin and thrombin-like enzyme) in a rabbit intramuscularly injected with sublethal dose of this venom.

C. rhodostoma venom was obtained from Latoxan (Rosans, France). Micro-ELISA plates were purchased from Nunc (Denmark). IgG-horseradish peroxidase conjugate (HRP) was from Bio-Rad Laboratories (USA). All chemicals and reagents utilized were of analytical grade (Sigma Chemical Company or Merck). C. rhodostoma venom hemorrhagin (called rhodostoxin) and thrombin-like enzyme were isolated as described in previous studies $(8,9)$. Protein concentration was determined by the Lowry method (10). Preparation of rabbit antisera against C. rhodostoma venom and the two venom components (rhodostoxin and thrombin-like enzyme) was carried out according to Tan and Ponnudurai (9). Double sandwich ELISA was accomplished following modifications by Harmon and Pawlik (11). Microtiter plates were coated overnight at $4^{\circ} \mathrm{C}$ with either purified IgG antibodies against the venom or venom components or IgG from preimmune serum (control). The plates were washed four times with PBS-Tween solution and the venom or venom components were added and incubated for two hours. After washing, IgG-HRP conjugate was added and incubated for another two hours, followed by addition of the substrate solution. Ten minutes later, the reaction was stopped by adding sulfuric acid.

One rabbit $(2 \mathrm{~kg}$ ) received intramuscularly a non-lethal dose of $C$. rhodostoma venom (1 mg/kg) $1 \mathrm{~cm}$ deep in its hind leg. The animal was bled (1 to $1.5 \mathrm{~mL}$ ) in the marginal ear vein at the following time intervals: $0.25 ; 0.5 ; 1 ; 2 ; 4 ; 6 ; 12 ; 24 ; 48 ; 72$; $96 ; 120 ; 144 ; 168$ and 192 hours. Pre-injection serum was used as control. Dilutions (1:5 to 1:10) of obtained sera were assayed in triplicate for C. rhodostoma venom and venom components by double sandwich ELISA. Appropriate dilutions of $C$. rhodostoma venom (1.5 to $50 \mathrm{ng} / \mathrm{mL}$ ) or venom components (0.5 to $12.5 \mathrm{ng} / \mathrm{mL}$ ) were employed to construct the respective standard curves. The concentration of the 
snake venom or venom components from the test serum was then read from the appropriate standard curves.

There was a progressive increase in absorption of $C$. rhodostoma venom from the inoculation site into the blood stream. The venom antigen levels in serum peaked $(42.6 \mathrm{ng} / \mathrm{mL}) 12$ hours after the injection and then gradually declined. Antigens were not detectable 192 hours post-injection (Figure 1 - A). C. rhodostoma venom antigen concentrations found in rabbit serum ranged from a few $\mathrm{ng} / \mathrm{mL}$ to $47 \mathrm{ng} / \mathrm{mL}$, and are of the same order of magnitude as those reported in sera of envenomated patients. For example, plasma venom levels of patients bitten by $C$. rhodostoma varied from $175 \mathrm{ng} / \mathrm{mL}$ (patients with non-clotting blood) to $35 \mathrm{ng} / \mathrm{mL}$ (patients with no gross clotting abnormalities) (12).

Barral-Netto et al. (1) reported that in mice injected with Bothrops jararaca venom, the venom antigen peaked after 15 minutes. Thereafter serum levels of venom dropped progressively and venom was not detectable 24 hours after injection. Similar pharmacokinetics was reported in rats injected with Bothrops erythromelas venom (13). A recent study that utilized dogs injected with Crotalus durissus terrificus venom, however, indicated that blood venom levels remained high 48 hours after intoxication (6). It is therefore obvious that the rate of venom clearance from blood circulation differs from species to species. However, all the results (including our findings) indicated that there was a fast absorption of venom from the inoculation site, followed by slow clearance of venom from circulation, which is indicative of a slow diffusion rate of venom components to other tissues. Our results also undoubtedly indicated that venom components bind to tissues at the injection site and that conjugated components were continuously released into circulation.

The C. rhodostoma thrombin-like enzyme antigen levels in the rabbit serum also increased progressively after the injection and peaked at of $2.5 \mathrm{ng} / \mathrm{mL}, 48$ hours after injection (Figure 1 - B). Afterwards, its levels decreased slowly and was negligible five days after the venom administration. This serum kinetic profile is similar to that of thrombin-like enzyme in rats reported by Zhao et al. (14). On the other hand, serum kinetics of rhodostoxin exhibited a biphasic profile (Figure $1-C$ ). Serum rhodostoxin levels were high $(1.3 \mathrm{ng} / \mathrm{mL}) 15$ minutes post-injection, indicating a rapid absorption of venom components. However, levels had dropped slightly to $0.9 \mathrm{ng} / \mathrm{mL}$ at one hour, and then progressively increased and reached a peak $(1.9 \mathrm{ng} / \mathrm{mL}) 12$ hours after the inoculation. After that, serum rhodostoxin levels gradually decreased, 
becoming negligible 120 hours after the injection. The cause of this biphasic profile of rhodostoxin is not clear. Observation of prolonged high serum levels of both thrombin-like enzyme and hemorrhagin is consistent with the clinical symptom of prolonged clotting defect in victims of severe C. rhodostoma envenomation (15).

It is interesting to note that, using double-sandwich ELISA technique, the serum kinetics profiles of $C$. rhodostoma venom components do not correspond to that of $C$. rhodostoma venom antigen. While both serum venom and rhodostoxin levels peaked 12 hours post-injection, serum thrombin-like enzyme was maximized 48 hours postinjection. Also, while only a very small amount of injected venom antigen appeared to remain in blood circulation at 72 hours post-injection, Figure 1 ( $B$ and $C$ ) shows that the thrombin-like enzyme and hemorrhagin levels in serum were both still relatively high at this moment. Presumably, the thrombin-like enzyme and hemorrhagin have higher affinity for tissue at the inoculation site and are therefore released into the circulation at a slower rate.

Our results therefore show that the various venom components have different rates of release into and clearance from the circulation, which implies that the "average composition" of "venom antigen" in the circulation of the victim is changing over time after venom inoculation. This indicates that results obtained from the usual practice of using antibodies against "whole" venom as reagents in ELISA for serum venom antigen quantification must be interpreted with care. 



Figure 1. Serum kinetics of (A) Calloselasma rhodostoma venom and venom components (B: thrombin-like enzyme; $\mathbf{C}$ : rhodostoxin) in a rabbit following a single intramuscular injection of a non-lethal dose of the venom. 


\section{ACKNOWLEDGEMENTS}

This work was supported by research grants IRPA-03-07-04-097 and 06-02-03-1001 from the Government of Malaysia.

\section{REFERENCES}

1. Barral-Netto M, Schriefer A, Vinhas V, Almeida AR. Enzyme-linked immunosorbent assay for the detection of Bothrops jararaca venom. Toxicon. 1990;28(9):1053-61.

2. Chase P, Boyer-Hassen L, Mcnally J, Vazquez HI, Theodorou AA, Walter FG, Alagon A. Serum levels and urine detection of Centruroides sculpturatus venom in significantly envenomated patients. Clin Toxicol. 2009;47(1):24-8.

3. Havivatvong O, Mahasandana S, Karnchanachetanee C. Kinetic study of Russell's viper venom in envenomed patients. Am J Trop Med Hyg. 1997;57(5):605-9.

4. Jacome D, Melo MM, Santos MM, Heneine LG. Kinetics of venom and antivenom serum and clinical parameters and treatment efficacy in Bothrops alternatus envenomed dogs. Vet Hum Toxicol. 2002;44(6):334-8.

5. Riviere G, Choumet V, Audebert F, Sabouraud A, Debray M, Scherrmann JM, Bon C. Effect of antivenom on venom pharmacokinetics in experimentally envenomed rabbits: toward an optimization of antivenom therapy. J Pharmacol Exp Ther. 1997;281(1):1-8.

6. Sangiorgio F, Sakate M, Nogueira RMB, Araujo JR, Chavez-Olortegui C. Kinetics of venom and antivenom serum levels, clinical evaluation and therapeutic effectiveness in dogs inoculated with Crotalus durissus terrificus venom. J Venom Anim Toxins incl Trop Dis. 2008;14(1):100-12.

7. Selvanayagam ZE, Gopalakrishnakone P. Test for detection of snake venoms, toxins and venom antibodies: review on recent trends (1987-1997). Toxicon. 1999;37(4):565-86.

8. Ponnudurai $\mathrm{G}$, Chung $\mathrm{MC}, \operatorname{Tan} \mathrm{NH}$. Isolation and characterization of $\mathrm{a}$ hemorrhagin from the venom of Calloselasma rhodostoma (Malayan pit viper). Toxicon. 1993;31(8):997-1005.

9. Tan $\mathrm{NH}$, Ponnudurai $\mathrm{G}$. An investigation on the antigenic cross-reactivity of Calloselasma rhodostoma (Malayan pit viper) venom hemorrhagin, thrombin-like enzyme and L-amino acid oxidase using enzyme-linked immunosorbent assay. Toxicon. 1994;32(10):1265-9. 
Tan NH et al. Serum kinetics of Calloselasma rhodostoma (Malayan Pit Viper) venom components in a rabbit. J Venom Anim Toxins incl Trop Dis. 2009;15(2):346

10. Peterson GL. Determination of total protein. Methods Enzymol. 1983;91:95-119.

11. Harmon MW, Pawlik KM. Enzyme immunoassay for direct detection of influenza type A and adenovirus antigens in clinical specimens. J Clin Microbiol. 1982;15(1):511.

12. Brown AE, Brown L. Blood venom antigen levels after Malayan pit viper bite. Trans R Soc Trop Med Hyg. 1987;81(4):548.

13. Rocha ML, Valenca RC, Maia MBS, Guarnieri MC, Araujo IC, Araujo DAM. Pharmacokinetics of the venom of Bothrops erythromelas labeled with ${ }^{131}$ I in mice. Toxicon. 2008;52(3):526-9.

14. Zhao $\mathrm{H}$, Zheng $\mathrm{J}$, Jiang $\mathrm{Z}$. Pharmacokinetics of thrombin-like enzyme from venom of Agkistrodon halys ussuriensis determined by ELISA in the rat. Toxicon. 2001;39(12):1821-6.

15. Reid HA, Chan KE, Thean PC. Prolonged coagulation defect (defibrination syndrome) in Malayan viper bite. Lancet. 1963;1(7282):621-6. 